\title{
A Comparative Study of the Quality of Higher Education Provision in Public and Private Universities in Bangladesh
}

\author{
Dr. Md. Ruhul Amin \\ Associate Professor \\ Department of Public Administration \\ Comilla University, Cumilla-3505, Bangladesh \\ E-mail: rubel@cou.ac.bd \\ Md. Rashidul Islam Sheikh \\ Associate Professor \\ Department of Public Administration \\ Comilla University, Cumilla-3506, Bangladesh \\ E-mail:mrisheikh@cou.ac.bd
}

Received: April 24, 2021

Accepted: May 6, 2021

Published: June 5, 2021

doi:10.5296/gjes.v7i1.18725

URL: https://doi.org/10.5296/gjes.v7i1.18725

\begin{abstract}
The evolution of a modern society largely depends on the essence of quality higher education. In a developing country, higher education has enormous potential to foster its development. Universities all over the world are changing actors of culture and remain the center of transformation and growth. Different Education Commissions have been formed in Bangladesh to explore the potentialities and create highly skilled human resources to contribute the national development (Topader, 2021). Due to the economic and globalization change emphasis on the quality education in education policy across the world. As a result, policymakers, academicians, and professionals in Bangladesh have expressed various issues regarding the quality of higher education. Over the last two decades, the standard of higher education in Bangladesh has steadily deteriorated (Rabbani \& Chowdhury, 2014). In this regard, the government, ministry, and UGC have taken various initiatives to ensure quality
\end{abstract}




\section{Macrothink}

Global Journal of Educational Studies

ISSN 2377-3936

higher education, especially at the tertiary level, to meet global demand. In this regard, this research aims to learn more about a particular scenario of higher education quality and investigate policy options for higher education in Bangladesh. In this connection, this study tried to determine the specific design of quality higher education and analyze the policy options for higher education in Bangladesh.

Keywords: Quality, Higher education, Public university, Private university, Bangladesh 


\section{Introduction}

Bangladesh is a fertile alluvial land having a long history in the area of education in South Asia. Therefore, of its fast population growth and low literacy rates, traditional schooling systems fail to satisfy the public demands of the people and lack educational resources, both formal and informal.

The beginnings of the current tertiary teaching-learning methodology in Bangladesh may be traced to the times of British India (Islam, 2011). Bangladesh has more than 41 public and 103 private universities with more than three million students (around 28 lakh students in public universities and 3.37 lakh students in private universities as per the Annual Report 2016 of the UGC (Khalid, 2019). There are different levels of education in Bangladesh, and these are primary, secondary, and tertiary levels of education. Tertiary education is divided into two types of institutes in Bangladesh: degree-awarding as well as college affiliated to the National University. The growth and development of modern society depend upon the philosophy and the quality of higher education. The total contribution and support of government and NGOs have extended significantly during the last two decades into the education arena of Bangladesh. Under the supervision of the University Grants Commission, Universities offer undergraduate, graduation, and doctorate degrees (Khan, 2015).

Quality higher education is a precarious development element in the contemporary world (Syed, 2019). The education system, specifically higher education, has undergone a drastic change in the last two decades. Intending to provide education to all, the government set up technical universities in every area where they were allowed to give affiliation to private institutions based on the self-financing model. This initiative led to the mushrooming growth of educational institutes throughout the country. The third essential dimension, i.e., excellence, had somehow been compromised to provide education to the masses. In the last two decades, the education system, significantly higher education has changed dramatically. To provide education to all, the government established technical universities all over the country that allowed private institutions to affiliate with them under a self-financing model. As a result, educational institutes sprung up all over the country (Namita, 2019).

Therefore, in the age of globalization and to reach the Sustainable Development Goals (SDGs) by 2030 , bridging the development junction through high-quality education, which we considered crucial and vital. Simultaneously, numerous benchmarks are available for improving quality education but still uncover the existing institutional gap. As a result, this study will focus on the institutional drawbacks and how they will improve quality higher education that meets the development junction by 2030 in Bangladesh. The main target of higher education is to produce new knowledge, exploring research works on diverse development issues, requires a strong economy, and makes a skillful workforce. Higher education must be universal, welfare, and sustainable by nature (Alam, Mahmudul, \& Haque, 2002). This study tried to find out the existing causes and consequences of quality higher education in public as well as private universities in Bangladesh and how to overcome exiting situations of these universities. 


\section{MlMacrothink}

\section{Research Objectives}

The research objectives of the study are given below:

\subsection{General Objective of the Study}

The study's general objective was to determine the factors contributing to the quality of higher education at the tertiary level in Bangladesh.

\subsection{Specific Research Objectives}

The specific research objectives were:

i) To focus on the teaching-learning system in tertiary level education,

ii) To find out the challenges of quality education in tertiary level education,

iii) To explore administrative and management drawbacks in tertiary level education, and

iv) To identify the expectations and barriers of students in tertiary level education.

\section{Rationale of the Study}

The research was necessary and vital on some grounds. Firstly, this research has added value to the current stock of literature by creating new knowledge on education, significantly at a higher level, along with budgetary proviso for higher education. Quality higher education is essential to survive in the global village. Therefore, it is assumed that budgetary allocation has affected on quality of higher education. Considering the facts, the academicians have tried to determine the association between quality of higher education and financial allocations (Masum, 2009). This study attempted to disclose all the primary determinants that affect the quality of higher education in Bangladesh. Secondly, the survey results will help the policymaker and the policy thinkers upgrade our existing education system. They will take this system as world-class. Lastly, this analysis would contribute to the proper execution of policies to enhance the quality of higher education in Bangladesh.

\section{Research Methodology}

Generally, research methodology is a method of collecting data for achieving the research goal. The qualitative and quantitative research approaches were used in this study. The primary data is gathered in October-December 2019, respectively.

\subsection{Sampling}

Ten (10) public and private universities from Dhaka, Rajshahi, and Cumilla have been selected purposively in this study. The study area was finalized based on quality education. The Primary data was collected through interviews and questionnaire surveys.

Sample Size: A total number of 400 respondents were collected based on purposive sampling from the following categories: 
Table 1. Scenario of study area and respondents

\begin{tabular}{|c|c|c|c|c|}
\hline Location & $\begin{array}{c}\text { Name of Public University and } \\
\text { Respondents }\end{array}$ & $\begin{array}{l}\text { Sample } \\
\text { Size }\end{array}$ & $\begin{array}{c}\text { Name of Private University and } \\
\text { Respondents }\end{array}$ & $\begin{array}{l}\text { Sample } \\
\text { Size }\end{array}$ \\
\hline Dhaka & $\begin{array}{l}\text { (a) University of Dhaka (Mgt, } \\
\text { Teachers, Students \& Staffs) } \\
\text { (b) Jagannath University (Mgt, } \\
\text { Teachers, Students \& Staffs) }\end{array}$ & 40 & $\begin{array}{l}\text { (a) North South University, (Mgt, } \\
\text { Teachers, Students \& Staffs) } \\
\text { (b) BRAC University, (Mgt, } \\
\text { Teachers, Students \& Staffs) }\end{array}$ & 40 \\
\hline Rajshahi & $\begin{array}{l}\text { (a) University of Rajshahi (Mgt, } \\
\text { Teachers, Students \& Staffs) } \\
\text { (b) RUET (Mgt, Teachers, } \\
\text { Students \& Staffs) }\end{array}$ & 40 & $\begin{array}{l}\text { (a) Varendra University (Mgt, } \\
\text { Teachers, Students \& Staffs) } \\
\text { (b) North Bengal International } \\
\text { University (Mgt, Teachers, } \\
\text { Students \& Staffs) }\end{array}$ & $\begin{array}{l}40 \\
40\end{array}$ \\
\hline Cumilla & $\begin{array}{l}\text { (a) Comilla University (Mgt, } \\
\text { Teachers, Students \& Staffs) }\end{array}$ & 40 & $\begin{array}{l}\text { (a) Britannia University (Mgt, } \\
\text { Teachers, Students \& Staffs) }\end{array}$ & 40 \\
\hline & No. of Public Universities: 5 & 200 & No. of Private Universities: 5 & 200 \\
\hline
\end{tabular}

\subsection{Sources of Data and Methods of Data Collection}

The data collection sources were primary and secondary. Secondary data was collected from the existing literature, e.g., books, daily reports, earlier research works, seminar papers, etc. The primary data was collected through interviews as well as by a semi-structured questionnaire guide.

\subsection{Methods of Data Analysis and Presentation}

The collected data was scrutinized, sorted, reviewed, computed, edited, configured, presented, and categorized, matching the study's objective. In addition, data were administered methodically in many research approaches as per the predetermined variables-age, education, occupation, and income categorized based on a qualitative method.

\section{Findings and Analysis}

\subsection{Scenario of Public Universities}

The scenario of quality education of public universities is discussed below:

\subsubsection{Vision, Mission, and Objectives}

The following figure revealed that either stakeholder perceives the vision, mission, and objectives or not. The feedbacks of the stakeholders are given below: 


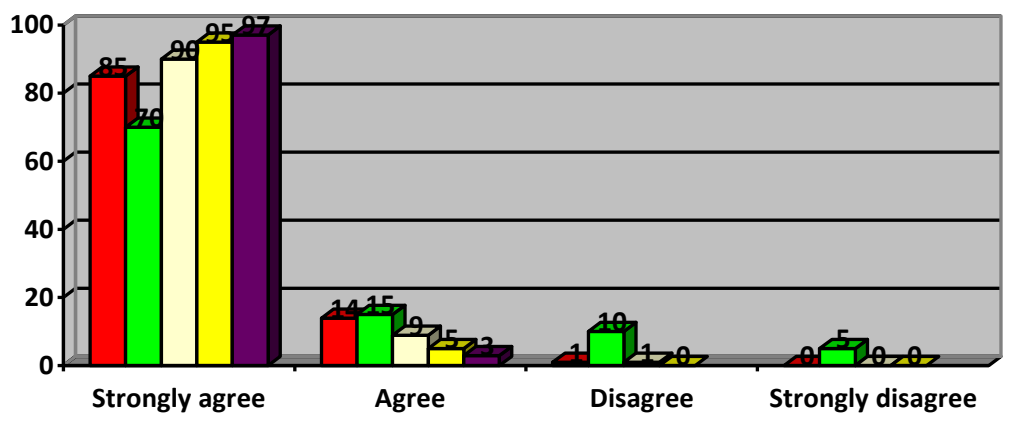

\begin{tabular}{|l|}
\hline Student \\
$\square$ Alumni \\
$\square$ Teacher \\
$\square$ Academic Staff \\
$\square$ Non-academic Staff
\end{tabular}

Figure 1. Scenario of vision, mission, and objectives

Source: Field Visits (2019).

The above diagram shows that all the stakeholders are well informed about the universities' vision, mission, and objectives. Almost all respondents (85\% students, 70\% alumni, 90\% teachers, $95 \%$ academic staff, 97\% Non-academic staff) strongly agreed. Another, minimum respondents (14\% student, 15\% alumni, 9\% teacher, 5\% academic staff, and 2\% non-academic staff) agreed to have a piece of knowledge about the key information of universities. Very few respondents disagreed and strongly disagreed with the statements.

\subsubsection{Scenario of Maintenance Academic Calendar}

An academic calendar is a part of an academic session, and based on its schedule, the educational institution holds classes. The class calendars adopted vary widely according to the nature of educational institutions. An Academic year is comprised of two Teaching Periods, January to June and July to December. In this regard, we have tried to identify the actual scenario of the academic calendar, either it is followed or not.
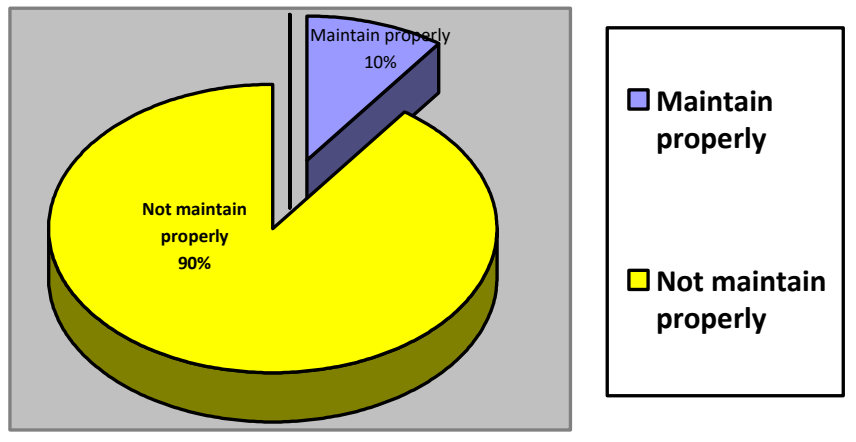

Figure 2. Scenario of maintenance academic calander

The above figure focuses on the scenario of the maintenance of the academic calendar. From a public university perspective, the scenario was disappointing. Ninenty percent of respondents said that the academic calendar was not appropriately maintained, which caused 


\section{Macrothink}

Global Journal of Educational Studies

ISSN 2377-3936

2021, Vol. 7, No. 1

session jams. The remaining 10 percent replied positively that the academic calendar was appropriately maintained and that the students completed their graduation in time.

The following figure indicates the causes behind why the academic calendar did not maintain properly:

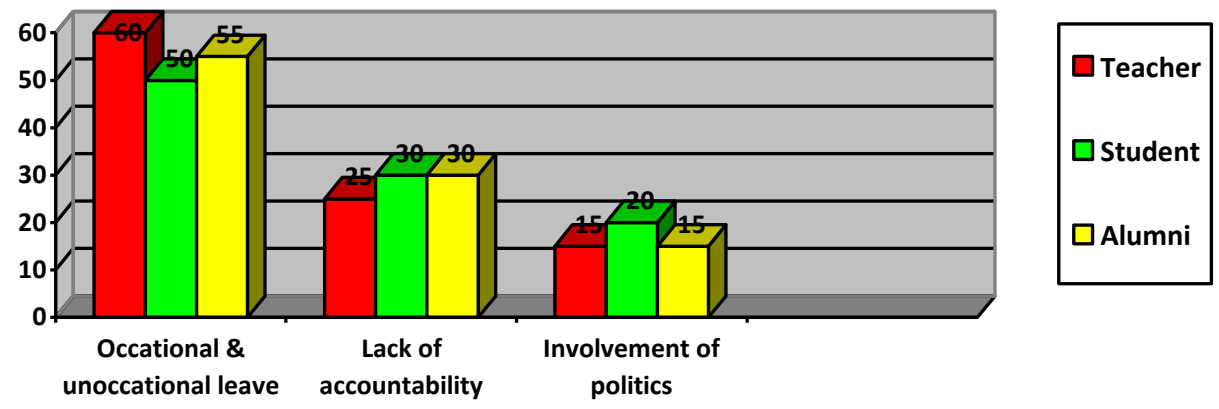

Figure 3. Causes behind the maintenance of academic calander

The figure shows that 60 percent of teachers, 50 percent of students, and 55 percent of alumni said a considerable amount of occasional and un-occasional leave hampered the academic atmosphere and the maintenance of the academic calendar. This kind of leave causes an unusual session jam. Another 15 percent of teachers, 20 percent of students, and 15 percent of alumni argued that involvement of different level politics regularly hampered the fulfillment of the academic calendar.

\subsubsection{Scenario of Review and Updating of the Academic Curriculum}

Review and update the academic curriculum are very important to meet the global need. To produce effective and efficient graduates, it is therefore essential to review and update the academic curriculum regularly.

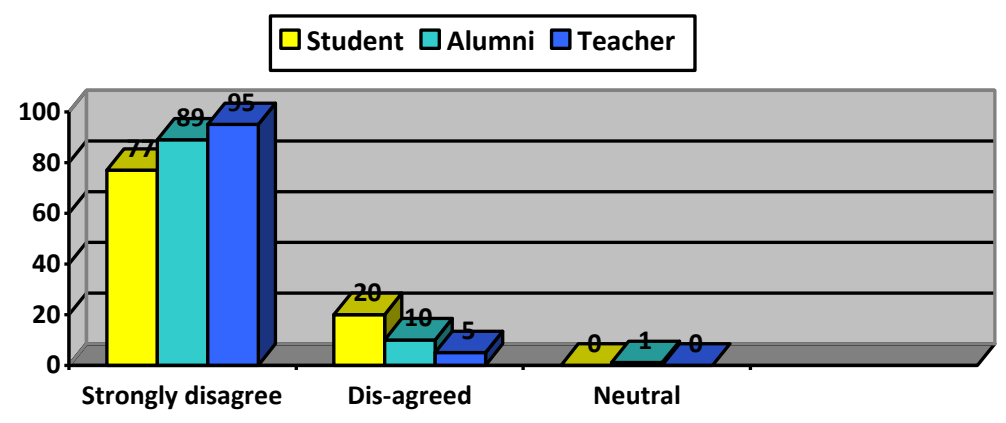

Figure 4. Scenario of Review and Updated Academic Calander

From the above diagram, almost 77 percent of students, 89 percent alumni, and 95 percent of the teachers strongly disagreed that the academic curriculum is not appropriately maintained. Another 20 percent of students, 10 percent alumni, and 5 percent teachers disagreed with this 


\section{Macrothink}

Global Journal of Educational Studies

ISSN 2377-3936

2021, Vol. 7, No. 1

issue. In contrast, only 1 percent of alumni are in neutral response on this issue. Based on these outcomes, it can be assumed that though some of the students, alumni, and teachers agreed. Simultaneously, most of the respondents did not concur that the academic curriculum is appropriately maintained.

\subsubsection{Scenario of Classroom Facilities}

A classroom should be a quiet place where the teachers and students can have mental satisfaction and peace and concentrate without any outer distractions. Classroom facilities could profoundly impact teacher and student outcomes and affect teacher recruitment, retention, commitment, and effort. In another perspective, classroom amenities affect health, behavioral pattern, engagement, learning, as well as progress in achievement.

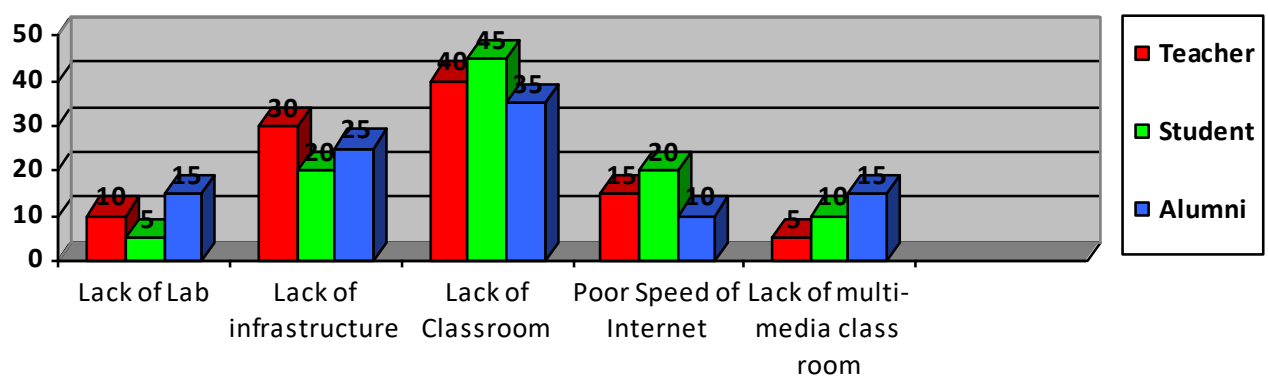

Figure 5. Opinion of classroom facilities for ensuring effective learning

In this survey, 10 percent of teachers, 5 percent of students, and 15 percent of alumni said that the existing lab facility and accommodation were not sufficient for the departments. Another 30 percent of teachers, 20 percent of students, and 25 percent of alumni claimed insufficient infrastructure hampered their teaching-learning environment. On the other hand, 40 percent of teachers, 45 percent of students, and 35 percent of alumni argued that lack of sufficient classrooms was one of the vital causes limiting the ensuring of quality education. Another 5 percent of teachers, 10 percent of students, and 15 percent of alumni claimed that the shortage of multimedia classrooms hinders the teaching-learning environment.

\subsubsection{Scenario of Diverse Methods used in Teaching-learning and Objectives}

The approach to teaching and learning incorporates numerous variables. These variables interact as learners work for their goals and assimilate new knowledge, behaviors, and skills which complement to their range of learning capabilities. During the past century, a variety of approaches to learning have emerged, among them cognitive and constructivist. 


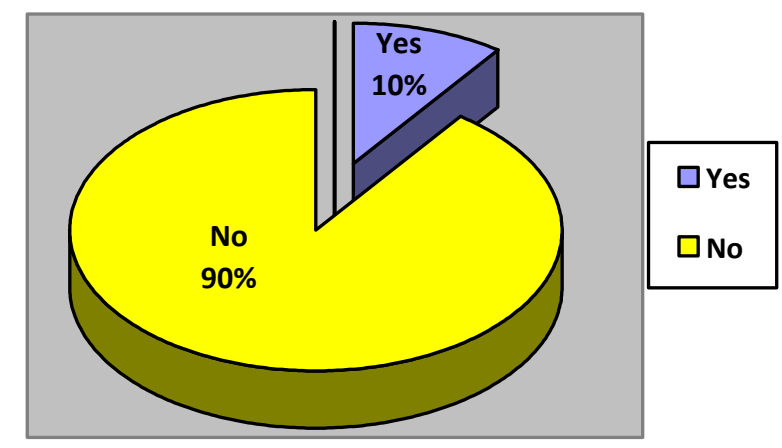

Figure 6. Utilization of diverse methods on teaching-learning

The reason why respondent claimed that modern methods were not used in the teaching-learning aspect are given below:

Table 2. Causes of non-utilization of diverse methods on teaching-learning

\begin{tabular}{|l|c|c|c|c|}
\hline S. L & $\begin{array}{c}\text { Lack of multimedia } \\
\text { classroom }(\boldsymbol{\%})\end{array}$ & $\begin{array}{c}\text { Lack of technical } \\
\text { expertise (\%) }\end{array}$ & $\begin{array}{c}\text { Lack of modern } \\
\text { equipment } \mathbf{( \% )}\end{array}$ & $\begin{array}{c}\text { Lack of supportive } \\
\text { technical staff }(\boldsymbol{\%})\end{array}$ \\
\hline Teacher & 30 & 15 & 20 & 35 \\
\hline Student & 35 & 20 & 20 & 25 \\
\hline Alumni & 35 & 25 & 15 & 25 \\
\hline
\end{tabular}

From the above table, 30 percent of teachers, 35 percent of students, and 35 percent of alumni argued that lack of multimedia classrooms hampered the teaching-learning traits. Another 15 percent of teachers, 20 percent of students, and 25 percent of alumni said that lack of technical expertise hampers the standard teaching-learning atmosphere. Additionally, 20 percent of teachers, 20 percent of students, and 15 percent of alumni argued that due to lack of modern equipment, interactive teaching-learning systems were not available in the classroom, so the respondents were unhappy with this existing situation. Furthermore, 35 percent of teachers, 25 percent of students, and 15 percent of alumni importantly claim that lack of supportive technical staff it was complicated to maintain the existing modern electronic devices.

\subsubsection{Scenario of Training and Workshop for Staff's Skill Development}

Training and workshops are crucial to enhancing personal skills, which smoothen the public service delivery. That is why arranging regular training and workshops is crucial to co-opt new dimensions and technology for better service delivery. 


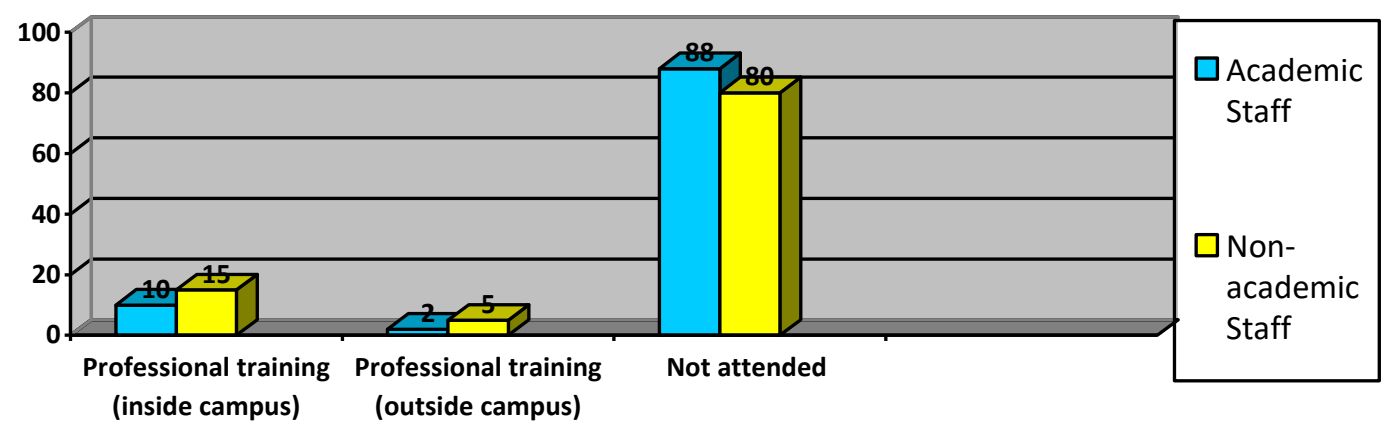

Figure 7. Facilities of staff's skill development program

The above table shows that 10 percent of academic staff and 15 percent of non-academic staff got their professional training within the campus and arranged by the university authorities. In comparison, 2 percent of academic staff and 5 percent non-academic staff got professional training in different organizations outside of their campus nominated by the university authorities. The respondents said that proper training facilities helpful to enrich their expertise. However, 88 percent of academic staff and 80 percent non-academic staff would not get any training from inside or outside the campus. The poor scenario indicates the low level of training facilities provided by universities.

\subsubsection{Scenario of Research and Development Policy}

Research is an integral part of higher educational institutions. But the budget allocation as well as the research policies and facilities are still very poor. That is why very little meaningful research we have seen over the year. Maximum teachers and students were involved in different types of activities accept research because of insufficient research policies.

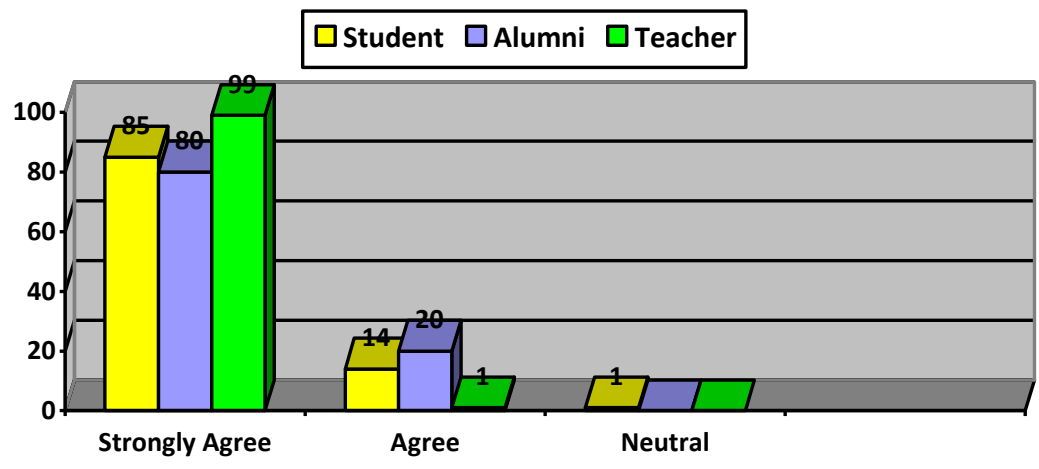

Figure 8. Scenario of research policies and facilities

From the above diagram, most of the respondents (85\% students, $80 \%$ alumni, and $99 \%$ teachers) strongly agreed and said that research and development strong policies were essential. They strongly suggest imposing and implement the research and development policies. Another 14 percent Of students, 20 percent of alumni, and 1 percent of teachers agreed to effective strong research policies to compete global universities need. On the other hand, only 1 percent of students were neutral to give any vital information regarding this 


\section{Macrothink}

issue.

\subsection{Scenario of Private Universities}

The scenario of quality education in private universities of Bangladesh are discussed below:

\subsubsection{Vision, Mission, and Objectives}

The following figure reveals how the stakeholder of private universities perceives the vision, mission, and objectives. The feedbacks of the stakeholders are given below:
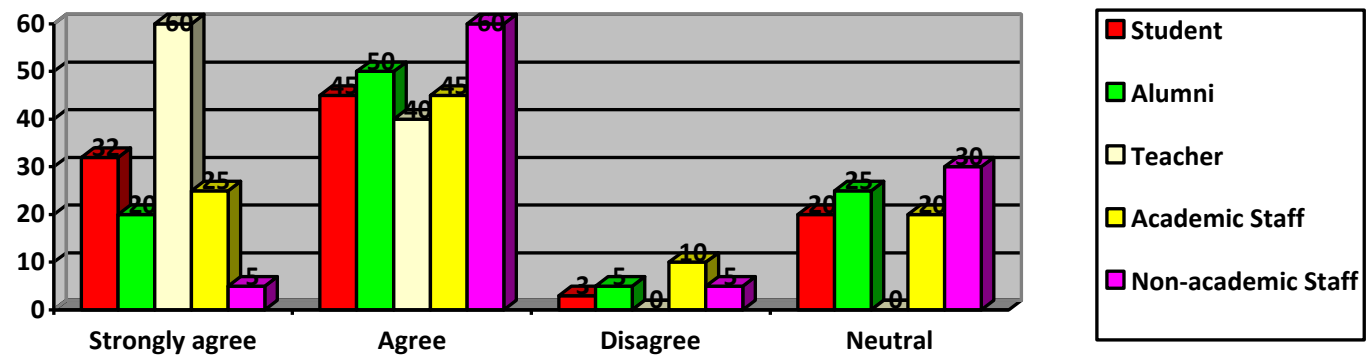

Figure 9. Scenario of vision, mission, and objectives

The above diagram revealed that 22 percent of students, 20 percent of alumni, 60 percent of teachers, 25 percent of academic staff, and 5 percent of non-academic staff strongly agreed with the institution's statements. Other maximal respondents, including 45 percent of students, 50 percent of alumni, 40 percent of teachers, 45 percent of academic staff, and 60 percent of non-academic staff, agreed that they know the basic information of private universities. Remarkably few respondents disagreed and strongly disagreed with these statements. On the other hand, 20 percent of students, 25 percent alumni, 20 percent academic staff, and 20 percent non-academic staff were neutrally responsible.

\subsubsection{Scenario of Maintenance of Academic Calendar}

An academic calendar is a part of an academic session and is based on its schedule the educational institutions holds classes. The schedules adopted vary widely according to the nature of the educational institutions. An academic year in Bangladesh is comprised of two teaching periods, January to June and July to December. In this regard, we have tried to identify the actual scenario of the academic calendar, and whether it is followed or not. 


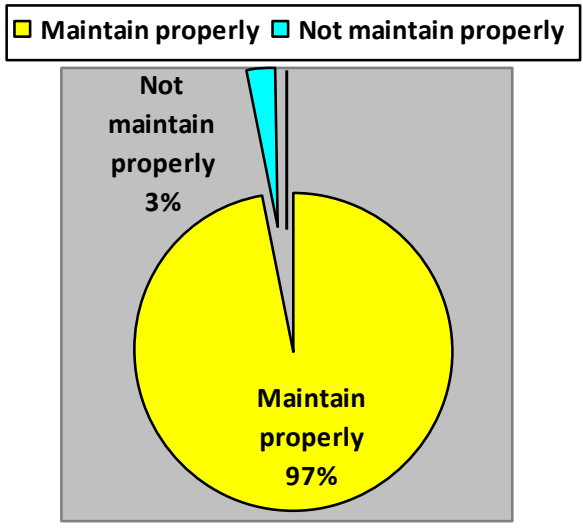

Figure 10. Scenario of maintenance academic calander

The above figure shows that 97 percent of respondents argued that the academic calendar was maintained strictly and adequately. For this reason, we have not found massive session jams in private universities. Another 3 percent of respondents replied that the academic calendar was not maintained properly, which causes a session jam that hampers completed graduation in time.

The following figure indicates the factors by which the academic calendar was maintained properly:

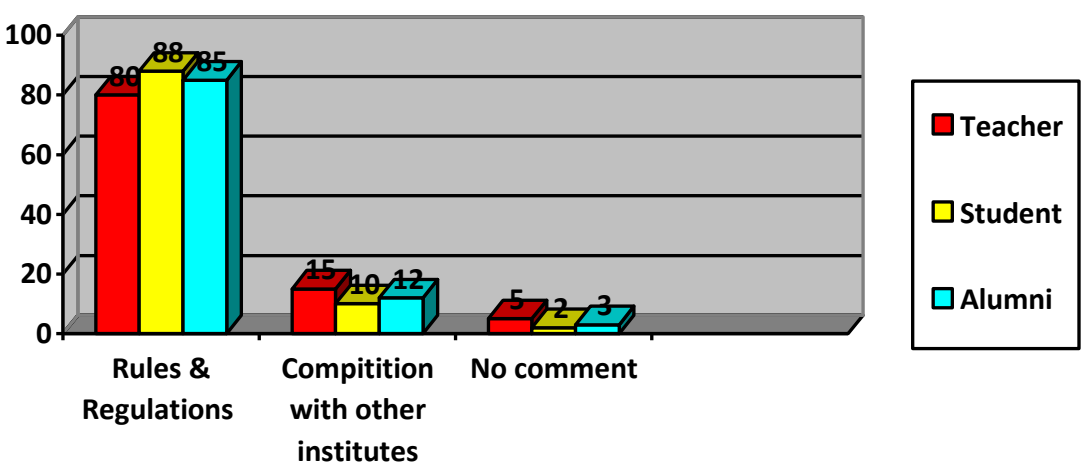

Figure 11. Causes behind maintain of Academic Calander

The above figure identified that 80 percent of teachers, 88 percent of students, and 85 percent of alumni mentioned that existing rules and regulations enforce the academic atmosphere and maintain the academic calendar properly. The findings help to overcome unusual session jams. Another 15 percent teacher, 10 percent student, and 12 percent alumni argued that competition with other institutions, private universities maintain academic calendar properly to be highlighted as better institutions for quality education. In addition, 5 percent of teachers, 2 percent of students, and 3 percent of alumni did not feel interested in providing any information regarding this question.

\subsubsection{Scenario of Review and Updated the Academic Curriculum}

Review and update the academic curriculum is very important to meet the global need. 


\section{Macrothink}

Global Journal of Educational Studies

ISSN 2377-3936 2021, Vol. 7, No. 1

Therefore, to produce effective and efficient graduates is vital to review and update the academic curriculum regularly.

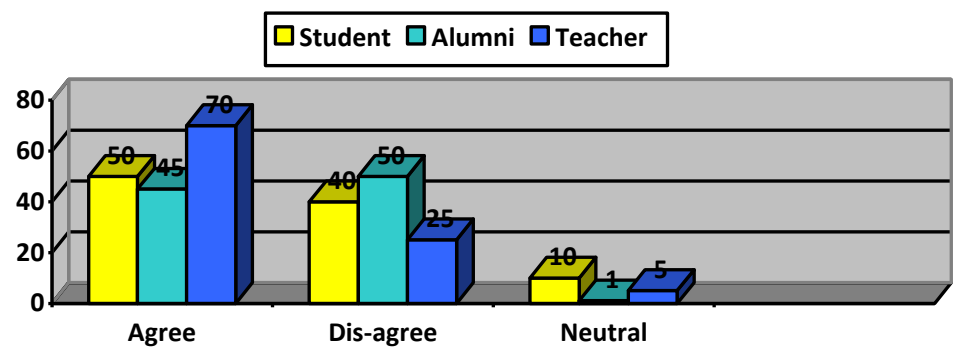

Figure 12. Scenario of review and updated academic curriculum

From the above diagram, almost 50 percent of students, 45 percent alumni, and 70 percent of teachers agreed that the academic curriculum was appropriately maintained. Another 40 percent of students, 50 percent of alumni, and 25 percent of teachers disagreed with this issue. In contrast, only 10 percent of students, 1 percent alumni, and 5 percent of teachers were neutral in response to this issue.

\subsubsection{Scenario of Classroom Facilities}

A classroom should be a quiet place where the teachers and students can have mental satisfaction and peace and concentrate without any outer distractions. Classroom amenities can have a great impact on both teachers and students as well as student outcomes. For teachers and students, classroom amenities affect teacher employment, retention, dedication, and effort.
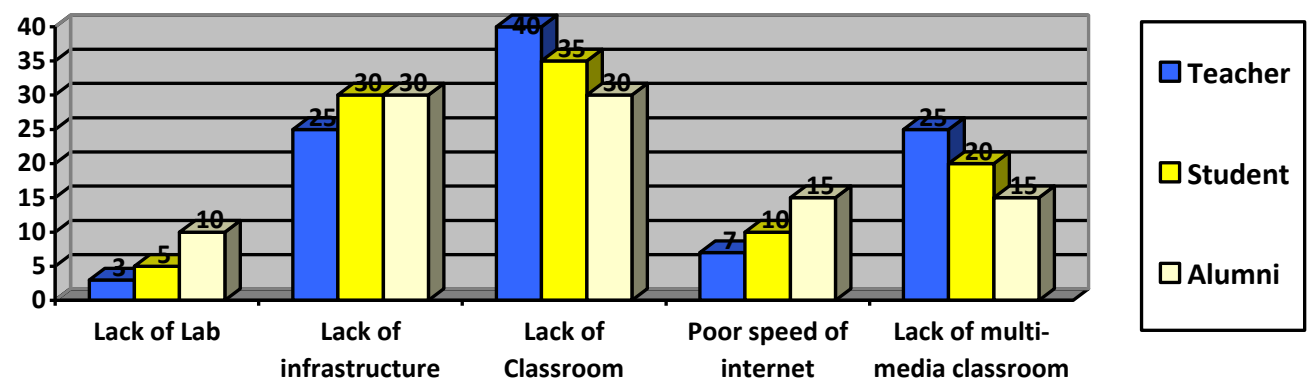

Figure 13. Opinion of classroom facilities for ensuring effective learning

From the above diagram, almost 50 percent of students, 45 percent alumni, and 70 percent of teachers agreed that the academic curriculum was appropriately maintained. Another, 40 percent students, 50 percent alumni, and 25 percent teachers disagreed with this issue. In contrast, only 10 percent of students, 1 percent alumni, and 5 percent of teachers were neutral in response to this issue.

\subsubsection{Scenario of Classroom Facilities}

A classroom should be a quiet place where the teachers and students can have mental 
satisfaction and peace and concentrate without any outer distractions. Classroom amenities can have a significant impact on both teachers as well as student outcomes. For teachers and students, classroom amenities affect teacher employment, retention, dedication, and effort.

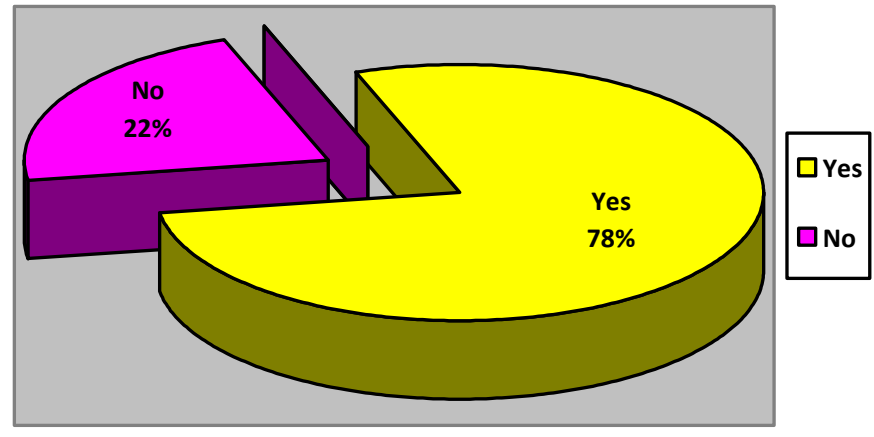

Figure14. Scenario of diverse methods used in teaching-learning

The reason why the respondent claims to use modern methods in the teaching-learning aspect are given below:

Table 3. Causes of the non-utilization of diverse methods on teaching-learning in private universities

\begin{tabular}{|l|c|c|c|c|}
\hline S. L & $\begin{array}{c}\text { Lack of Multimedia } \\
\text { classroom (\%) }\end{array}$ & $\begin{array}{c}\text { Lack of Technical } \\
\text { expertise (\%) }\end{array}$ & $\begin{array}{c}\text { Lack of Modern } \\
\text { equipment (\%) }\end{array}$ & $\begin{array}{c}\text { Lack of Supportive } \\
\text { technical staff (\%) }\end{array}$ \\
\hline Teacher & 30 & 25 & 25 & 20 \\
\hline Student & 40 & 25 & 20 & 15 \\
\hline Alumni & 35 & 20 & 15 & 30 \\
\hline
\end{tabular}

From the above figure, 30 percent of teachers, 40 percent of students, and 35 percent of alumni argued that lack of multimedia classroom hampered the teaching-learning traits. Another 25 percent teacher, 25 percent student, and 20 percent alumni said that lack of technical expertise hampers the standard teaching-learning atmosphere. Besides, 25 percent of teachers, 20 percent of students, and 15 percent of alumni argued that interactive teaching-learning systems were not available in the classroom due to lack of modern equipment, so the respondents were unhappy with this existing situation. Furthermore, 20 percent of teachers, 15 percent of students, and 30 percent of alumni importantly claim that it was complicated to maintain the existing modern electronic devices due to lack of supportive technical staff.

\subsubsection{Scenario of Training and Workshop for Staff's Skill Development}

Training and workshop are crucial to enhance personal skills, which smoothen the public service delivery. From public universities' perspective, new dimension and update technology utilization are the common phenomena. That is why arranging regular training and workshops is crucial to co-opt new dimensions and technology for better service delivery. The following figure presented the existing training and workshop facilities for the regular 
staff in the universities.
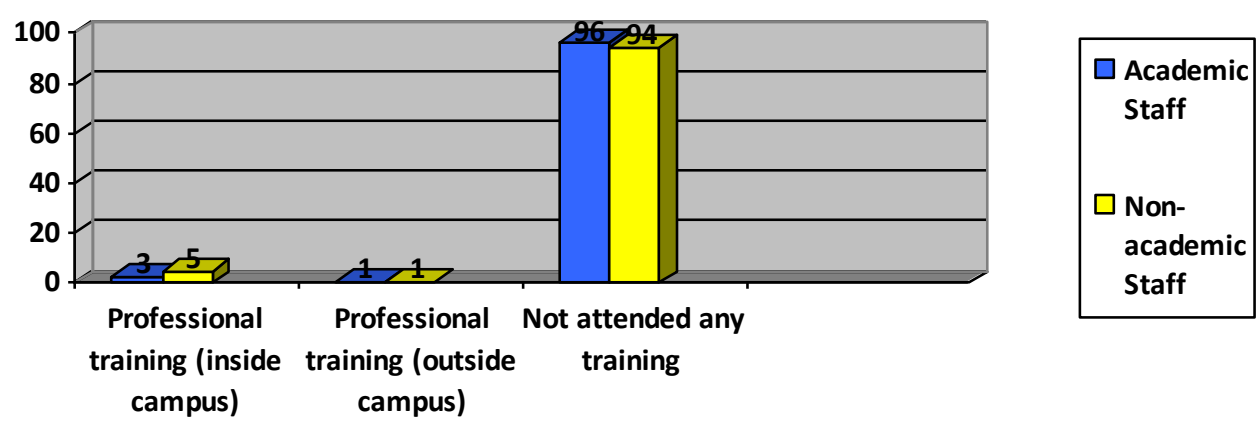

Figure 15. Facilities of staff's skill development program

From the above figure, 3 percent of academic staff and 5 percent non-academic staff have professional training within the campus arranged by the university authorities. In comparison, 1 percent of academic staff and 1 percent of non-academic staff got professional training outside of their campus in different organizations nominated by the university authorities. However, 96 percent of academic staff and 94 percent non-academic staff would not get any training from inside or outside their campus. The poor scenario indicates the low level of training facilities of employees in the private universities.

\subsubsection{Scenario of Research and Development Policy}

Research is an integral part of higher educational institutions. But the budget allocation as well as the research policies and facilities are still very poor. That is why we have seen very little meaningful research over the year. Most teachers and students were involved in different types of activities to undertake research because of inadequate research policies.

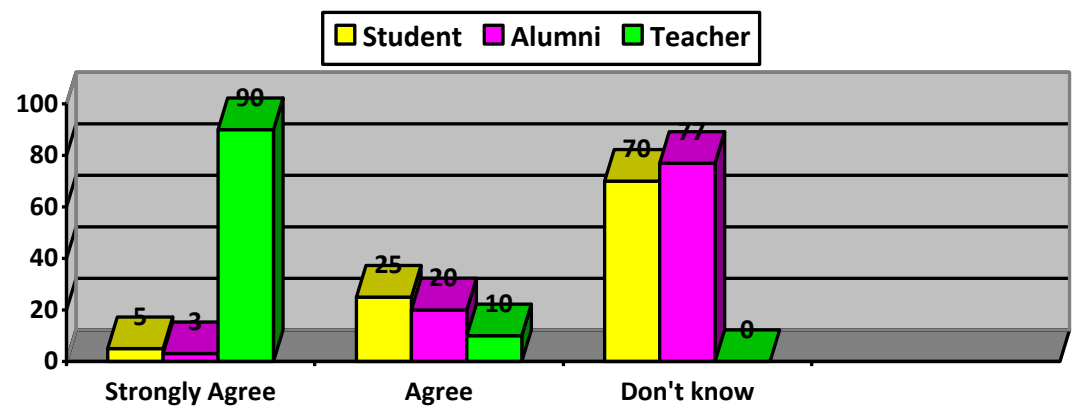

Figure 16. Scenario of research policies and facilities

From the above diagram, it can be concluded that very few of the respondents, 30 percent of students, 23 percent of alumni agreed and said that they knew that their educational institute has the research and development policies, while cent percent of teachers said that their institution has research and development policies. But 70 percent of students and 77 percent of alumni disagreed and said that they did not know there if there were any research and development policies existing or not. 


\subsection{Comparative Study of Quality Education between Public and Private Universities}

The study is correlated to compare the quality of educational provision in public and private universities, the respondents were selected from five stakeholders. The primary respondents were selected among students of their second years of degree studies. All 400 respondents participated, and the generated answers were indicative to the outcomes.

Table 4. Comparative study of quality education factors between public and private universities

\begin{tabular}{|c|l|c|c|c|c|}
\hline \multirow{2}{*}{ S. L } & \multicolumn{1}{|c|}{ Features of Quality Education } & \multicolumn{2}{c|}{$\begin{array}{c}\text { Public } \\
\text { Universities (\%) }\end{array}$} & \multicolumn{2}{c|}{ Private } \\
Universities (\%)
\end{tabular}

There are some close values in the above table between the returns from stakeholders regarding quality education among public and private universities in Bangladesh. The findings showed that public and private universities lack of qualified and efficient faculty members along with logistic facilities. The stakeholders also claimed that research funding and facilities were not sufficient to enable quality research to be conducted. There was no quality assurance system in public universities due to its being unavailable or never maintained in the academic calendar. In this regard, almost the same scenario is found in private universities. More importantly, in both the public and private universities, it is almost impracticable to re-arrange the curricula in view of the present needs.

\section{Recommendations}

Analyses this study, the following recommendations are made. We all need to improve the human capital of Bangladesh by improving its moral, knowledge-based, and financial capital. By improving the quality of higher education is the best way to achieve these targets. The following recommendations are, therefore, will enrich the quality of education at the tertiary level of Bangladesh:

a. The strategic focus of quality must generate better human resources outcomes, strengthening professional, social, and national excellence.

b. Higher education commissions, education authorities, and universities must revise existing education policies to compete with global needs.

c. Logistic support and technical assistant must ensure that both universities get quality education compared to developed countries, which will dictate the appropriate learning process. 
d. Course materials and lesson plans should be supplied earlier to the student to prepare themselves for the class.

e. Non-stop broad-band and Wi-Fi Internet facilities must be available for the teacher-student and staff; therefore, they should quickly collect information, e-learning, and e-communication.

f. Delivering training and workshops to the teacher, student, academic, and non-academic staff will help them to enrich their expertise.

g. Provide a handsome research fund and lab facilities in both public and private universities; therefore, teacher-student can introduce various types of research. Worldwide standard recognition is quite impossible without quality research.

h. The coordination between the fundamental and applied research institutions should be ensured. The libraries and laboratories should be sufficiently equipped by allocating more budgetary allocations.

i. Expanding poverty-targeted scholarship and tuition support for the students (World Bank, 2019).

\section{Conclusion}

Quality of education is needed to prepare skilled human resources for the job market, but it needs to boost economic productivity (Hosen, 2019). The government of Bangladesh is very concerned about quality education from the primary to tertiary levels of education. In this regard, the government has already taken meaningful initiatives to modernize the education sector. We are very optimistic about the Strategic Plan for Higher Education in Bangladesh: 2006-2026, which is already prepared by the University Grants Commission of Bangladesh (Fakhrul, 2008). In this study, we have tried to determine the current teaching-learning scenario in Bangladesh's public and private universities. Due to the shortcomings compared with other developing countries globally, the atmosphere of tertiary education is not satisfactory.

Nevertheless, in this study, we tried to determine the factors responsible for the quality of higher education. We have found a lack of motivation, politicization, lack of lab facilities, low level of the research grant, pushing tertiary education in poor situation. These are common scenarios in public and private universities in Bangladesh. We must rethink the standard and quality of higher education and improve the quality of education at the tertiary level. Instead of prioritizing theoretical education, we will need to start research-based tertiary education in Bangladesh. 


\section{References}

Alam, M., \& Haque, M. S. (2002). Private Higher Education. In UNESCO Report.

Fakhrul, I. (2008). Some Issues of Higher Education in Bangladesh: Analysis of Demand, Problems and Trends. Prime University Journal, 2(02).

Hosen, S., \& Shafiul, I. (2019). Ensuring Quality Education at Tertiary Level in Bangladesh. https://doi.org/10.13140/RG.2.2.22876.21125

Islam, Y. (2011). Tertiary Education in Bangladesh. Brief History, Problems and Prospects. $5(2)$.

Khalid, H.(2019). Why are university graduates failing to meet market needs? The Daily Star Newspaper, Dhaka, Bangladesh.

Khan, Md. M. (2015). Information Needs and Information Seeking Behaviour of Faculty Members of Public Universities in Dhaka Division, Bangladesh (Ph.D Thesis) (Issue May).

Masum, M. (2009). Higher Education in Bangladesh: Problem and Policies. In World Bank Report on Bangladesh.

Namita, G. (2019). Quality Assessment Framework for Technical Education in India: A Study of Technical Institutions (Ph.D Thesis). 2019.

Rabbani, G., \& Chowdhury, S. (2014). Quality of Higher Education in Bangladesh. Governance, 7(1), 78-91.

Syed, M. M. (2019). Declining standard of tertiary level education. The Independent Newspaper.

Topader, R. A. (2021). Vision 2021 and Sustainable Development Goals can be achieved. World Bank. (2019). Bangladesh Tertiary Education Sector Review.

\section{Copyright Disclaimer}

Copyright for this article is retained by the author(s), with first publication rights granted to the journal.

This is an open-access article distributed under the terms and conditions of the Creative Commons Attribution license (http://creativecommons.org/licenses/by/3.0/). 